\title{
Mutual impact of personal income tax and macroeconomic indicators
}

\author{
Article history: \\ Received: 3 April 2020 \\ Sent for revision: 20 September 2020 \\ Received in revised form: 12 October 2020 \\ Accepted: 18 October 2020 \\ Available online: 4 December 2020
}

\begin{abstract}
From mid-2006 to the end of 2008, numerous decisions were adopted in the public finances of the Republic of Serbia, which resulted in a permanent reduction in tax revenues and in increase of public expenditures. It creates a systemic imbalance between government revenue and expenditure, that is, the fiscal deficit. The emergence of the fiscal deficit is the main motive of the conducted research, where by using a simple regression analysis of the time series of macroeconomic data, authors linked the indicators of economic growth and personal income tax. The results of the research indicate the importance of the influence of personal income tax on the creation of a favorable macroeconomic environment, where the regulation and reform of the existing tax system are imposed as imperatives.
\end{abstract}

Keywords: payroll tax, macroeconomic indicators

\section{Međusobni uticaj poreza na dohodak građana i makroekonomskih indikatora}

Apstrakt: Od sredine 2006. do kraja 2008. godine, u javnim finansijama Republike Srbije usvojen je niz odluka koje imaju za posledicu trajno smanjenje poreskih prihoda i povećanje javnih rashoda. Na taj način formira se sistemska neravnoteža između prihoda i rashoda države, odnosno fiskalni deficit. Pojava

\footnotetext{
${ }^{1}$ University of Defense, Military Academy, Belgrade, curcicmihailo@gmail.com

2 Institute for Applied Sciences, Belgrade

${ }^{3}$ University for Business Studies, Banja Luka
} 
fiskalnog deficita predstavlja glavni motiv sprovedenog istraživanja, gde su autori, uz pomoć proste regresione analize vremenske serije makroekonomskih podataka, doveli u vezu pokazatelje privrednog rasta i poreza na dohodak građana. Rezultati istraživanja govore o važnosti uticaja poreza na dohodak građana na kreiranje povoljnog makroekonomskog ambijenta, gde se kao imperativ nameće regulisanje i reforma postojećeg poreskog sistema.

Ključnereči: porez na dohodak građana, makroekonomski indikatori

\section{Introduction}

There are numerous definitions of an income, depending on the nature and manner of operation of a given tax system, however, the essence is the same: income is the sum of all net income that a taxpayer is earning during one tax year. The taxable net income can be defined as the difference between gross income and expenses (contributions).

Looking at the classification of the tax system of the Republic of Serbia, we can conclude that the personal income tax has a character of the genus term, including the tax on wages, taxes on the income from self-employment, taxes on property income, taxes on income from copyrights and industrial property rights, capital gains taxes and other income taxes. Those are tax subjects for residents, and the amount of taxes varies depending on the income or profit. It is generally calculated as a product of the tax rate and tax base, net of nontaxable income.

According to Popović (2017) diversified taxable net income may appear as a pool in the sum that represents taxable income. Also, all income can basically be classified into three categories, namely: employment income, operating income and investment income. Since the tax system of the Republic of Serbia is based on a cedular construction, different taxes are subject to different legal tax rates of 10,15 or $20 \%$, with the effective rates being even more differentiated. 
Figure1.Tax System of the Republic of Serbia

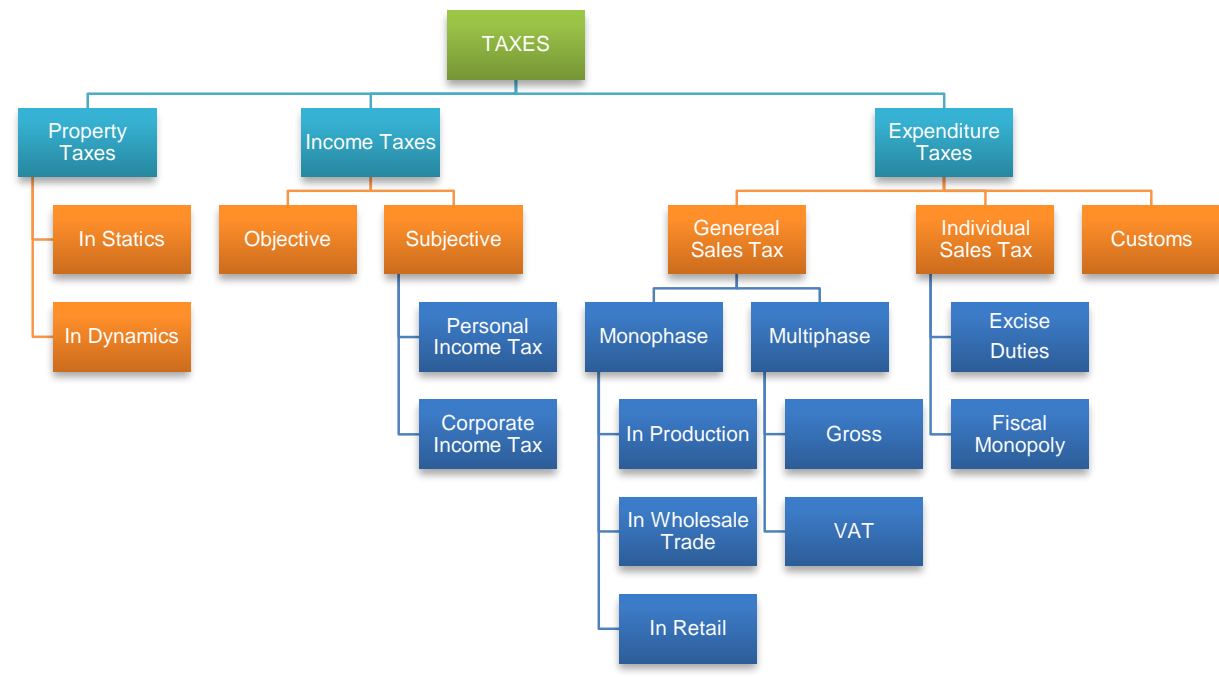

Source: Raičević, B. (2008). Public Finances. Economics Faculty, Belgrade

Table 1.Tax rates of Personal income tax in the Republic of Serbia

\begin{tabular}{|l|c|c|}
\hline \multicolumn{1}{|c|}{ Type of Income } & $\begin{array}{c}\text { Tax Rate } \\
\text { (in \%) }\end{array}$ & Standardized Costs \\
\hline Earnings & 10 & 16.300 din. \\
\hline Income from self-employment & 10 & In Accordance With the Tax Balance \\
\hline Royalties & 20 & $50 \%-43 \%-34 \%$ \\
\hline Income from Capital & 15 & - \\
\hline Real Estate Income & 20 & - \\
\hline Capital gains & 15 & \\
\hline Other Income & 20 & \\
\hline
\end{tabular}

Source: Personal Income Tax Law

The tax system established in 1991 was, at one time, one of the most modern systems. Due to the political situation, pre-war conditions and destabilization of the entire country, which caused an unprecedented rise in inflation, it has been used for less than two years. As a result, a wave of new reforms had created another tax system in hope that it would resist the impact of inflation. Personal income taxation was continued with the new Law on Personal Income Tax, the provisions of which were largely transcribed from the Law passed in 1991,

Industrija, Vol.48, No.3, 2020 
which meant continued implementation of the mixed system. All income, except those explicitly exempted by law, is taxed cedularly, and if the taxpayer generates income in the tax period beyond the amount stipulated by the Law, additional taxation is made with the annual income tax. Despite all the shortcomings, this Law on Personal Income Tax has not undergone some significant changes, but has been frequently amended in the last 15 years, and is still being implemented in the almost same form as in time of its adoption (Kovačević et al., 2017). In order to create and implement active employment policy measures, the legislative framework is created by the laws of the Republic of Serbia, which can significantly assist the unemployed in finding jobs (in terms of incentives for employers) and unemployment insurance (Simić et al., 2019).

The aim of this paper is a contribution to the consideration of the mutual impact of personal income tax and macroeconomic indicators of the Republic of Serbia, from a scientific point of view. The results of this research are stimulating a reflection on possible reforms of the tax system in order to establish fuller fairness in the tax burden of taxpayers, and also to ensure a more harmonious functioning in relation to national macroeconomic policies. The hypothesis, raised at the beginning of this research, is that the value of the collected personal income tax affects the outcomes of macroeconomic indicators, and, therefore, the economic growth of the Republic of Serbia.

\section{Literature review}

In the previous period, criticisms on the effectiveness of fiscal policy, as well as macroeconomic policy in general were frequent, which resulted in numerous studies of the academic community, in order to make certain contribution to overcoming the obstacles (Dubauskas, 2019). The tax system as an instrument of a country's fiscal policy directly affects the level of public revenues (AlvarezMartinez \& Polo, 2018). However, the efficiency of collecting public revenues through taxes is related to the tax relief provided by the state leadership. It is worth mentioning that the results of the research of Palić et al. (2019) reflected the assessment of the impact of selected labor market factors and personal income taxes. It is also claimed that the level of the average monthly wages and the number of employees are affecting the efficiency of the personal income tax in the long run (Urban et al., 2019). Taking it into consideration, the authors confirmed the correlation of previously mentioned indicators. Regarding the analysis of economic growth, it should be noted that, depending on individual components in the process of defining the dynamics of economic growth, economic policy makers stimulate investment activity of domestic and foreign investors through fiscal policy instruments (Vidović et al., 2019). 
As fiscal deficit causes fiscal policy and tax system changes, Arsić (2013) describe the period after the Global economic crisis in Serbia, stated that GDP and domestic spending were falling sharply, which made public finance problems more visible. If the Government had not taken discretionary measures, the actual fiscal deficit in 2009 would be $7-8 \%$ of GDP. However, in a relatively short period of time, the Government adopted a series of austerity and less popular measures, out of which freezing of wages and pensions was the most important, and it brought considerable savings in the context of relatively high inflation. As a result of the adopted measures, the real fiscal deficit in 2009-2010 was relatively low in Serbia, at 4,5-4,7\% of GDP, and was among lower fiscal deficits in Europe. However, since mid-2011, the Government has again made number of decisions that have resulted in the destabilization of the macroeconomic environment in the Republic of Serbia.

When it comes to linking the tax revenues and economic growth, ĐurovićTodorović \& Đorđević (2017) argue that corporate income tax, unlike the personal income tax, has a developing component, given that it has been imposed on the role of the implementer of numerous macroeconomic policy development goals. Taxpayers are provided with tax incentives to stimulate economic growth, mitigating regional and sector disparities in the economy, boosting employment, improving the environmental situation. In addition, tax incentives can also contribute to enhancing international competition. Pecić \& Trandafilović (2017) analyzed the world experiences and trends of countries in the region, and suggested that implementing a synthetic personal income tax would be complicated and counterproductive for the existing tax system in Serbia. On the other hand, given the experiences of countries that have implemented the transition process and faced obstacles in implementing progressive taxation, such as increasing tax evasion and capital outflows under inadequate tax administration, it would certainly be more preferable to introduce a proportional income tax in Serbia.

By examining the impact of personal income tax, corporate income tax, and social security contributions on economic growth in the United States from 1996 to 2016, Kalaš et al. (2017) found that personal income taxes and social security contributions are the most generous tax forms that make up more than $50 \%$ of U.S. tax revenues. The average shares of personal income tax, corporate income tax and social security contributions in the observed period were $9.14 \%, 2.13 \%$ and $6.3 \%$. The authors point out the growth of tax revenues and social security contributions as a significant impact on economic growth. The results show that a $1 \%$ increase in tax revenue and social security contributions increases gross domestic product by $0.3 \%$ and $2.05 \%$, respectively. 
Looking at specific issues from a statistical point of view, there are numerous research results on the effects of taxes on GDP (Okoli et al. 2014; Hunady \& Orviska, 2015; Gale et al. 2015; Etale \& Bingilar, 2016). However, bearing in mind that, in the context of linking personal income tax and economic growth, there is not a wide range of results of domestic research, authors observed and conceptualized their research in relation to the research results of Kalaš et al. (2017). The results of these authors confirmed the assumptions that personal income tax and corporate income tax do not have a statistically significant impact on GDP, such the VAT has in the case of the Republic of Serbia, which is an important difference compared to previous research in other countries. Also, by comparing these results and the results obtained by the research, we found significant differences. Regarding the foreign tax systems, Wolowiec (2018) state that the tax systems of the EU member countries are harmonized with the legal regulations and standards of the European Union. However, they express their sovereignty in terms of defining the tax category and tax rates, as well as tax deductions and tax reliefs, forming a unique tax framework. Taking into account the diversity of the socio-economic environment at the national level, tax deductions and tax relief depend on a single country. For instance, most countries set a single non-taxable amount of the personal income. This relief represents expenditure, but on the other hand it provides the possibility of elementary existence to citizens.

In his work, Zidar (2019) quantified the importance of the distribution of tax changes for their overall impact on economic activity. He believes that his results are important for characterizing central trade-offs on capital efficiency in tax policy, according to the following: if macroeconomic policy makers want to increase economic activity in the short run, tax cuts for those with the highest incomes are less effective than tax cuts for those with lower income. While it is possible that income tax reductions for those with the highest incomes have long-term impacts on various categories such as investing in human capital, business creation or innovation, much more convincing results are needed to support the reduction in the highest income taxes.

In a study of Latin American countries, Barreix et al. (2017) indicate, on the basis of the obtained data, that the personal income tax system is unquestionably progressive, and thus has a strong impact on the economic growth and development of countries in this part of America. However, the collection of income through personal income taxes is limited by existing tax breaks, which on average exempt almost $90 \%$ of the population from tax liabilities, including predominantly extremely high-income residents.

The survey of mutual impact of personal income tax and economic growth (Amin et al., 2018) shows the existance of long run bond between these two variables. The results present significant relation of personal income tax and 
economic growth in case of China and Pakistan. The authors stress that higher tax on salaries and wages of people leads to higher tax revenue which in turn will enhance economic growth. Likewise, Stoilova (2017) examined the tax structure of European Uninon and its impact on economic growth. The crucial result is that tax structure based on selective consumption taxes, taxes on personal income and property, is more supporting to the economic growth than other tax categories.

\section{Methodology}

The methodology used in this research is based on the application of a statistical method of simple regression. This method seeks to present the relationship between variables by setting a linear equation with respect to the observed data. One variable is considered explanatory and the others are considered as independent variables. Specifically, using this example, authors linked the values of annual personal income tax and macroeconomic indicators, such as real GDP growth, GDP value, unemployment rate, budget deficit/surplus, percentage of public debt and average earnings in the Republic of Serbia, over the period of 2009 to 2019.

Table 2.Observed Macroeconomic Indicators

\begin{tabular}{|c|r|r|r|r|r|r|c|}
\hline $\mathrm{Yr}$ & $\begin{array}{c}\text { Real } \\
\text { GDP } \\
\text { growth } \\
(\%)\end{array}$ & $\begin{array}{c}\text { GDP } \\
(\mathrm{mil.} €)\end{array}$ & $\begin{array}{c}\text { Unemployment } \\
\text { rate }(\%)\end{array}$ & $\begin{array}{c}\text { Average } \\
\text { Personal } \\
\text { Income } \\
(€)\end{array}$ & $\begin{array}{c}\text { Public } \\
\text { Debt } \\
\text { (\% of } \\
\text { GDP) }\end{array}$ & $\begin{array}{c}\text { Budget } \\
\text { deficit / } \\
\text { surplus } \\
\text { (\% of } \\
\text { GDP) }\end{array}$ & $\begin{array}{c}\text { Personal } \\
\text { Income } \\
\text { Tax (mil. } \\
\text { RSD) }\end{array}$ \\
\hline 2009 & $-2,7$ & 32.486 & 16,1 & 337,8 & 30,9 & $-3,0$ & $161.569,0$ \\
\hline 2010 & 0,7 & 31.546 & 19,2 & 331,8 & 39,5 & $-3,2$ & $173.426,5$ \\
\hline 2011 & 2,0 & 35.432 & 23,0 & 372,5 & 42,8 & $-3,8$ & $197.387,6$ \\
\hline 2012 & $-0,7$ & 33.679 & 23,9 & 366,1 & 52,9 & $-5,6$ & $215.874,0$ \\
\hline 2013 & 2,9 & 36.427 & 22,1 & 388,5 & 56,0 & $-4,9$ & $228.930,1$ \\
\hline 2014 & $-1,6$ & 35.467 & 19,2 & 379,8 & 66,2 & $-5,9$ & $216.222,5$ \\
\hline 2015 & 1,8 & 35.716 & 17,7 & 367,9 & 70,0 & $-2,7$ & $236.324,6$ \\
\hline 2016 & 3,3 & 36.723 & 15,3 & 374,5 & 67,8 & $-0,2$ & $281.207,1$ \\
\hline 2017 & 2,0 & 39.183 & 13,5 & 383,9 & 57,9 & 0,7 & $301.041,1$ \\
\hline 2018 & 4,4 & 42.855 & 12,7 & 419,7 & 53,7 & 0,6 & $323.734,2$ \\
\hline 2019 & 4,2 & 45.908 & 10,4 & 465,9 & 52,0 & 0,2 & \\
\hline
\end{tabular}

Source: National Bank of Serbia

The values of the mentioned macroeconomic indicators in Table 2 indicate similar oscillations in the observed time period. Based on these trends, authors are able to establish that there are two turning points in the negative trend, primarily the year 2013 for the unemployment rate $(22.1 \%$ - the highest value), 
or the year 2014, which brought an end to the negative trends in GDP $(35,467$ mils. $€$ ) and budget deficit (-5.9\% of GDP - the lowest value). At the end of 2015 , progress was observed in public debt ( $70 \%$ of GDP - the highest value) and the average level of personal income (367.9 euros). The only indicator that has continued to oscillate is the rate of real GDP growth. The value of personal income tax increased after 2014. In the conducted research, using the method of linear regression, we have analyzed the interrelation of personal income tax and the mentioned macroeconomic indicators.

The most common linear regression method is the least squares method. This method is used for calculation of the most appropriate line for the observed data by minimizing the sum of squares of vertical deviations from each data point to the line (if the point lies exactly on the line set, then its vertical deviation is 0 ). Since the deviations are first squared, then summed, there is no "idle" between positive and negative values.

After a regression line has been calculated for the data group, a point that lies far from the line (and therefore has a large backlog) is known as the outside. Such points may represent incorrect data or may indicate poor fit of the regression line. If the point lies far from the other data in the horizontal direction, this is known as an influential observation. The reason for this difference is that these points can have a significant effect on the slope of the regression line.

According to Todic (1973) this method consists in applying the principle that the sum of squares of deviations of points from the regression line is the smallest. This principle can be expressed analytically in the following relation:

$$
f(a, b)=\Sigma\left(y-a-b x_{i}\right)^{2}=\min
$$

Based on this principle, a normal system of two linear equations is formed as follows:

$$
\begin{aligned}
& \frac{\delta f(a b)}{\delta a}=-2 \Sigma\left(y-a-b x_{i}\right)=0 \\
& \frac{\delta f(a b)}{\delta b}=-2 \Sigma\left(y_{i}-a-b x_{i}\right) X_{i}=0
\end{aligned}
$$

or

$$
\begin{aligned}
& \Sigma y_{i}=N a+b \Sigma x_{i} \\
& \Sigma x_{i} y_{i}=a \Sigma x_{i}+b \Sigma x_{i}
\end{aligned}
$$


Similar to the trend of analysis, authors come up with patterns for an unknown parameter in the following forms

$\bar{a}=\bar{y}-b \bar{x}$

$b=\frac{\Sigma x_{i} y_{i}-\bar{y} \Sigma x_{i}}{\Sigma x_{i}^{2}-\bar{x} \Sigma x_{i}}$

If the coordinate origin is moved at the center of the independent phenomenon, then the form for $b$ can be simplified:

$b=\frac{\Sigma\left(x_{i}-\bar{x}\right) y_{i}}{\Sigma\left(x_{i}-\bar{X}\right)^{2}}$

Therefore, the regression equation takes shape

$\bar{y}_{i}=a+b x_{i}$

Once the regression model fits into the data group, the residual test (deviations from the fitted line to the observed values) allows the modeler to investigate the validity of his assumption that there is a linear relationship. Plotting the residual on the $\mathrm{Y}$ axis versus the explanatory variable on the $\mathrm{X}$ axis reveals any possible nonlinear relationship among the variables or may alert the modeler to investigate the scattering variables.

Data from the National Bank of Serbia (2009-2019) are taken as information source based on which this research was conducted.

\section{Results and discussion}

Before the hypothesis is tested, it is also necessary to check the normality of the data authors intend to use in testing. Data normality is determined using the Shapiro-Wilk test. This test was performed in the descriptive statistics, and the values obtained were above the significance threshold, for each variable. The assumption that $p$-values of linear regression are normally distributed across groups is acceptable. 
Table 3. Shapiro-Wilk test

\begin{tabular}{|c|c|c|}
\hline Variables & Shapiro-Wilk Coefficient & p-value \\
\hline Real GDP growth & 0,93822 & 0,49983 \\
\hline GDP & 0,90439 & 0,20898 \\
\hline Unemployment rate & 0,96454 & 0,82676 \\
\hline Average Personal Income & 0,91419 & 0,27316 \\
\hline Public Debt & 0,95194 & 0,66881 \\
\hline Budget deficit/surplus & 0,89895 & 0,17946 \\
\hline Personal Income Tax & 0,94681 & 0,63088 \\
\hline
\end{tabular}

Source: Research of the authors

A valuable numerical measure of the association between the variables is the correlation coefficient, whose value is between -1 and 1 , indicating the strength of the relatedness of the analyzed data.

The linear regression line has the equation of the form $Y=a+b X$, where $X$ is an explanatory variable (value of the personal income tax) and $Y$ is a dependent variable (macroeconomic indicators). The slope of the line is $b$ and $a$ is the intercept (the value of $Y$ when $X=0$ ).

Table 4. Research results

\begin{tabular}{|l|c|c|c|c|c|c|}
\hline & $R$ & $R^{2}$ & $\begin{array}{c}\text { Adjusted } \\
R^{2}\end{array}$ & $\begin{array}{c}\text { Std.Err. of } \\
\text { estimate }\end{array}$ & $\begin{array}{c}\text { Std.Coef. } \\
\text { of } b\end{array}$ & t-value \\
\hline Real GDP growth & 0,742 & 0,551 & 0,494 & 2,303 & 0,742 & 3,131 \\
\hline GDP & 0,927 & 0,859 & 0,841 & 0,008 & 0,927 & 6,976 \\
\hline Unemployment rate & 0,622 & 0,387 & 0,310 & 0,000 & $-0,622$ & $-2,245$ \\
\hline $\begin{array}{l}\text { Average Personal } \\
\text { Income }\end{array}$ & 0,831 & 0,691 & 0,652 & 0,000 & 0,831 & 4,228 \\
\hline Public Debt & 0,595 & 0,354 & 0,274 & 0,000 & 0,595 & 2,095 \\
\hline Budget deficit/surplus & 0,728 & 0,530 & 0,471 & 0,000 & 0,728 & 3,001 \\
\hline
\end{tabular}

Source: Research of the authors

$\mathrm{R}$ - the absolute value of the linear regression coefficient

$R^{2}$ - coefficient of determination

Adjusted $\mathrm{R}^{2}$ - corrected coefficient of determination (less biased)

Std.Err.of estimate - standard error in model estimation

Std.Coef.of $b$ - coefficient of relative importance in a regression model

t-value - null hypothesis test/significance test of regression coefficient for predictor variable (nonstandardized regression analysis coefficient divided by standard error in estimation) 
The value of $\mathrm{R}$ in the conducted regression analysis represents the coefficient of linear correlation between the two variables. Using the Chaddock scale (Bacho et al., 2019; Telizhenko et al., 2019), authors can determine a positive noticeable correlation $[0,5<\mathrm{R}<0,7]$ with the parameters of the unemployment rate and public debt in relation to the value of personal income tax. Then, values of the parameters of real GDP growth, budget deficit/surplus and average personal income are in the interval of $0,7<R<0,9$, representing a positive close correlation with the values of personal income tax. A strong correlation $(0,9<R<0,99)$ is observed between the value of GDP and personal income tax.

The coefficient of determination $\left(R^{2}\right)$ indicates that as much as $85.9 \%$ of the value of GDP is conditioned by the movement of the value of personal income tax, while the remaining $14.1 \%$ is a consequence of other influences. Also, it should be noted that only in the parameter of average personal income is the impact of personal income tax noticeable $(65.2 \%)$, while in other observed parameters this value is negligible.

The adjusted correlation coefficient (Adjusted $\mathrm{R}^{2}$ ) is presented in order to obtain indicators that will not increase unjustifiably with the increase in the number of explanatory variables. Therefore, only the GDP coefficient $(0,841)$ is statistically significant as the most appropriately related parameter to the independent variable. The coefficients of other parameters are not statistically significant. The largest established standardized error of estimated value in the assessment is in the case of real GDP growth, while this value is imperceptible or statistically insignificant in case of other parameters. Moreover, looking at the value of $t$ statistics, there is a positive effect of dependent variables, but only the impact on the GDP is statistically significant.

The value of the coefficient of relative importance of the dependent variable in the regression model coincides with the values of linear correlation $(R)$, where the value of $\operatorname{GDP}(0,927)$ should be emphasized. It is interesting that the relative value of the unemployment rate is shown with a negative sign, which actually indicates the inverse correlation of the dependent and independent variable.

\section{Conclusion}

Unlike previous research of Kalaš et al. (2017), obtained results indicate the existence of a statistically significant correlation between personal income tax and GDP. The results obtained in this study indicate, first of all, the strong correlation of the observed parameters and then the significance of the regression relationship of these indicators. Based on the results, authors can conclude that, in the case of the Republic of Serbia, controlling the personal 
income tax has an important role in creating favorable macroeconomic indicators and achieving macroeconomic goals. Therefore, it is imperative to regulate and reform the existing tax system, which, following the standards of the process of harmonization of the tax system with the tax systems of the European Union, contributes to sustainable economic growth and development, as well as to creating a favorable socio-economic environment.

Linking personal income tax and macroeconomic indicators of economic growth and development, which was conducted in this study in the case of the Republic of Serbia, is the starting point for examining detailed links between tax revenues of individual categories of personal income with macroeconomic indicators. Thus, the obtained results provide limited information on the relationship of selected indicators, while on the other hand, they ideologically encourage further research, providing a starting point. In authors' opinion, the following research should be conducted in two parts: the first would include examining the effectiveness of individual personal income taxes; while the second part would compare the results with the data of developed European countries, with a same or a similar social-political organization, by using a comparative method. That way, selected indicators would be obtained and scientific contribution would be reflected in giving recommendations to fiscal policy creators through the process of planning fiscal measures in the coming period.

\section{References}

Alvarez-Martinez, M. \& Polo, C. (2018). The cost of public deficit in Spain: Increasing tax rates and reducing public spending. El Trimestre Economico, 85(340), 833858. doi: 10.20430/etev85i340.521

Amin, A., Chen, Y. \& Huang, S. (2018). Personal Income Tax and Economic Growth: A Comparative Study Between China and Pakistan. Asian Journal of Economic Modelling, 6(1), 65-73. doi: 10.18488/journal.8.2018.61.65.73

Arsić, M. (2013, decembar). Fiscal policy and recovery of the Serbian economy. Challenges for Serbia's economic policy in 2013 (pp. 9-27). Belgrade, Serbia: Faculty of Economics (in Serbian) Retrieved from http://ndes.ekof.bg.ac.rs/downloadsakta/zbornik2012deo3.pdf\#page=9

Bacho, R., Pukala, R., Hlibko, S., Vnukova, N. \& Pola, P. (2019). Information Management: the Key Driver of the Economic System's Development. Marketing and Management Innovations, 3, 297-307. doi: 10.21272/mmi.2019.3-23

Barreix, A., Benítez, J. C., \& Pecho, M. (2017). Revisiting personal income tax in Latin America: Evolution and impact. OECD Development Centre, Working Paper No. 338 Retrieved from https://www.ciat.org/Biblioteca/Estudios /2017_Personal Income_Tax_LA_WP_338_OECD.pdf

Dubauskas, G. (2019). A potential influence of tax inequality on the sustainable public management. Journal of security and sustainability issues, $8(4), 775-784$. doi: 10.9770/jssi.2019.8.4(19) 
Đurović-Todorović, J. \& Đorđević, M. (2017). Mutual influence of inequality through the application of tax reliefs and exemptions in the system of profit taxation in the Republic of Serbia. Proceedings: Regional Development and Cross-Border Cooperation 2017, Board of Pirot Chamber of Commerce, 249-263 (in Serbian) Retrieved from http://konferencija.komorapirot.com/ZbornikRadova.PDF

Etale, L.M., \& Bingilar, P.F. (2016). The impact of company income tax and value- added tax on economic growth: Evidence from Nigeria. European Journal of Accounting, Auditing and Finance Research, 4(7), 106-112.

Gale, W., Krupkin, A., \& Rueben, K. (2015). The Relationship Between Taxes and Growth at The State Level: New Evidence. National Tax Journal, 68(4), 919-942. doi: dx.doi.org/10.17310/ntj.2015.4.02

Hunady, J., \& Orviska, M. (2015). The Non-linear Effect of Corporate Taxes on Economic Growth. Timisoara Journal of Economics and Business, 8(1), 14-31. doi: 10.1515/tjeb-2015-0002

Kalaš, B., Milenković, I., Pjanić, M., Andrašić, J. \& Milenković, N. (2017). The Impact of Tax Forms on Economic Growth - Evidence from Serbia. Industrija, 45(2), 113125, doi: 10.5937/industrija45-12978

Kalaš, B., Mirović, V., \& Andrašić, J. (2017). Estimating the impact of taxes on the economic growth in the United States. Economic Themes, 55(4), 481-499 doi: 10.1515/ethemes-2017-0027

Kovačević, M., llić, J. \& Damjanović, R. (2017). Evolution of income tax in Serbia. Oditor - Journal of Management, Finance and Law, 3(1), 7-22 (in Serbian) doi: $10.5937 / O d i t o r 1701007 \mathrm{~K}$

Okoli, M. N., Njoku, C.D., \& Kaka, G.N. (2014). Taxation and Economic Growth in Nigeria: A Granger Causality Approach.International Journal of Research in Management, Science \& Technology, 2(3), 64-80.

Owens, J. (2006). Fundamental Tax Reform: an International Perspecitive. OECD's Centre for Tax Policy \& Administration: National Tax Journal, 131-164.

Palić, I., Hodžić, S. \& Dumičić, K. (2019). Personal Income Taxation Determinants in Federation of Bosnia and Herzegovina. Business Systems Research, 10(1), 153163. doi: $10.2478 / \mathrm{bsrj}-2019-0011$

Pecić, N. \& Trandafilović, S. (2017). The role of personal income tax in budget formation. Revision: VII International Scientific Congress. Center for Economic and Financial Research, 127-139 (in Serbian).

Popović, D. (2017). Tax law. Belgrade: Faculty of Law (in Serbian)

Raičević, B. (2008). Public finances. Belgrade: Faculty of Economics (in Serbian)

Simić, N., Kosumi, T. \& Jialiang, Y. (2019). Regulatory instruments of sustainable development. Održivi razvoj, 1(1), 15-26, doi: 10.5937/OdrRaz1901017S (in Serbian)

Stoilova, D. (2017). Tax structure and economic growth: Evidence from the European Union. Contaduria y Administracion, 62(3), 1041-1057. doi: 10.1016/j.cya.2017. 04.006

Stojković, A. \& Gligorijević, M. (2016). The place of personal income tax in the structure of the tax system of Serbia. BizInfo, 7(1), 25-35. doi:10.5937/bizinfo1601025S (in Serbian) 
Telizhenko, O., Pavlenko, O., Martynets, V. \& Rybalchenko, S. (2019). Modeling the Influence of Cluster Components on the Economic Development of a Territory. TEM Journal, 8(3), 900-907. doi: 10.18421/TEM83-30

Todić, R. (1973). Basics of statistical analysis. Belgrade: Savremena administracija (in Serbian)

Urban, I., Čok, M. \& Verbič, M. (2019). The burden of labour taxation in Croatia, Slovenia and Slovakia in the period 2011-2017. Economic Research - Ekonomska istraživanja, 32(1), 1430-1456. doi:10.1080/1331677X

Vidović, N., Beriša, H. \& Dželetović, M. (2019). The impact of value added tax on the public finances of the Republic of Serbia. Vojno delo, 71(3), 234-245. doi: 10.5937 /vojdelo1903234V (in Serbian)

Wolowiec, T. (2018). Potential and Possible Ways of Harmonizing the Personal Income Taxation Process. Comparative Economic Research, 21(3), 109-130. doi: 10.2478/cer-2018-0022

Zidar, O. (2019). Tax cuts for whom? Heterogeneous effects of income tax changes on growth and employment. Journal of Political Economy, 127(3), 1437-1472. doi: $10.1086 / 701424$ 